Asian J. Med. Biol. Res. 2020, 6 (3), 408-417; doi: 10.3329/ajmbr.v6i3.49788

\author{
Asian Journal of \\ Medical and Biological Research \\ ISSN 2411-4472 (Print) 2412-5571 (Online) \\ www.ebupress.com/journal/ajmbr
}

\title{
Article \\ Impacts of climate change on fishers' livelihood in Kishoregonj haor region, Bangladesh
}

\author{
Ariful Islam, Md. Saddam Hossain and Zakir Hossain* \\ Department of Fisheries Biology and Genetics, Bangladesh Agricultural University, Mymensingh-2202, \\ Bangladesh \\ *Corresponding author: Zakir Hossain, Department of Fisheries Biology and Genetics, Faculty of Fisheries, \\ Bangladesh Agricultural University, Mymensingh-2202, Bangladesh. Phone: +8801724-939693; Fax: +88091- \\ 61510; Email: zakir.fbg@bau.edu.bd
}

Received: 20 July 2020/Accepted: 27 August 2020/ Published: 30 September 2020

\begin{abstract}
Kishoreganj haor region is highly sensitive to the climatic events such as flash flood, soil erosion, heavy rainfall, drought, storm surge etc. The aim of this research is to assess the impacts of climate change on fishers' livelihoods of Kishorganj haor region, Bangladesh. The fisher' livelihood data were collected through semi-structured questionnaire interview and Focused Group Discussion (FGD) method. In Kishoreganj haor region, natural disasters have increased due to climate change, that threat on fishers' livelihood by extinction of fish species, low fish availability, destructing houses and other infrastructures. In the present study, it was found that $65 \%$ fishers were involved in permanent fishing activity and $35 \%$ fishers were temporarily involved in fishing with other occupation as daily labour, net making etc. A very few empirical research on the impacts of climate change in Kishoreganj haor has been conducted, so researcher and policy makers can get information about the concern by this study and implement policy for the climate change induced affected people of the Kishoreganj haor.
\end{abstract}

Keywords: climate change; economic impact; fishers; hoar region; livelihood status

\section{Introduction}

Climate change has become a major concern all over the world. The emissions of greenhouse gases and increasing pre-existing concentration of these gases in the atmosphere are the prime cause to increase the global temperature (IPCC, 2007a). In the modern world, consumption of energy is increasing day by day. Currently, about $80 \%$ of the world's power is generated from fossil fuels which has been produced greenhouse gases that are affecting the global climate (ACIA, 2004; Ficke et al., 2007). The global average temperature is expected to increase by $0.2^{\circ} \mathrm{C}$ per decade over the next two decades. If temperature continue to increase at this rate, it adds, global average temperature increase (from 1905) will reach $1.5^{\circ} \mathrm{C}$ by 2050 (IPCC, 2007b). The concentration of atmospheric carbon dioxide is presently higher than any observed in the last 160,000 years (Dobson, 2001). However, the climate has very complex relationships with the seasonality including variations of temperature, rainfall and day length (Gill and Gerard, 1991). Such seasonal variation has diverse influence on fishing, fish production and livelihoods. The variation in the global climate or regional climate over time, such as variation in sunlight intensity, droughts, greenhouse gas emission, temperature rise, extreme temperature, unexpected rainfall, floods and cyclones, arsenic contamination, losses of ecosystem which caused by processes of internal and external forces (WFC, 2009).

Haor is mainly a bowl-shaped large tectonic depression covered by water almost six months of a year starting the monsoon which is the most productive ecosystem with huge number of environment, economic and social value (Kazal et al., 2010; Sarma et al., 2010). Additionally, it has diverse wetland habitats i.e. rivers, streams and irrigation canals, flooded plans and hundreds of haors and beels (Hussain and Salam, 2007). In Bangladesh, 423 haors in seven districts i.e. Habiganj, Moulavibazar, Sylhet and Sunamganj in the north-east, Netrokona and 
Kishoreganj in the north-central and Brahmanbaria in the central eastern region of Bangladesh is covered 8000 $\mathrm{km}^{2}$ (Miah, 2013). The haor region is surrounded on three sides by the mountain ranges of India, with Meghalaya to the north, Tripura and Mizoram to the south, and Manipur and Assam to the east. The region extends north to the end of the Garo and Khasia Hills and east along the upper Surma valley to the Indian border (Bennett et al., 1995).

Kishoreganj haor region is a vulnerable place with respect to climate change (Nath et al., 2010). This haor region is also a very much endangered area with diversified problems shortage of food, and damage due to floods, erosion, excess rain and loss of land. Due to the climate change on livelihood, fisheries resources, fishing ground and fish habitat may directly be affected in Kishoreganj haor region (Ahmed, 2012). Because of the haor ecosystems are altering gradually for changing water quality parameters by rising temperature. Climate change is altering species composition which has negative impact on ecosystem functions and productivity (Duffy, 2003). Species respond to climate changes and shifts in community dynamics have the impacts in abundance and changes of fish diversity (Schiel et al., 2004). Higher temperature reduces oxygen solubility in water, favour the survival of parasites and bacteria; these conditions will collectively reduce fish survival, affected the natural foods, growth and reproductive success of wild populations (Hall, 2009). Climate change affects fisheries in Kishoreganj haor region via, changes in temperature and circulation patterns, the frequency and severity of extreme events. Although higher temperature than ambient or near lethal temperatures allows fish to adjust critical limits in a few degrees by acclimation (Myrick and Ceck, 2003). When fish is exposed to temperature within the sub lethal range, its can still be affected by the environmental temperature. The metabolic rates of fish are affected in majority due to water temperature.

Climate change is a serious threat to the Kishoreganj haor region with its high concentrations of population and economic activity. Fishers' communities are considered vulnerable to the negative impacts of climate change (Dixen et al., 2003). The visible impacts of climate change in Kishoreganj haor region include temperature rising, storm surge damage, loss of wetlands, loss of freshwater fish habit, loss of biodiversity, damage boats, nets, fishing gear, and fish landing centres, as well as education, health, housing, and other community infrastructure (Adger et al., 2005; Westlund, 2007). Climate change will tend to exacerbate non-climatic pressures on fisheries such as overfishing, pollution and loss of habitat (Brander, 2006; Sumalia et al., 2011). In addition, fishing is considered high-risk livelihood activity due to the fugitive nature of the resource, the hostile environment of the fishing and perishability of the product (MRAG, 2011). The livelihood vulnerability can be assessed using the sustainable livelihood approach (SLA) (Badjeck et al., 2010). The asset base- human, physical, natural, financial and social capital forms the building block of livelihoods and helps to reduce vulnerability.

\section{Materials and Methods}

\subsection{Study area}

The area of Karimganj upazila of Kishoreganj is $200.52 \mathrm{~km}^{2}$, located between $24^{\circ} 22^{\prime}$ and $24^{\circ} 32^{\prime}$ north latitudes and in between $90^{\circ} 48^{\prime}$ and $91^{\circ} 01^{\prime}$ east longitudes. It is bounded by Tarail and Itna upazilas on the north, Nikli, Kataidi and Kishoreganj Sadar upazilas on the south, Nikli and Mithamoin upazilas on the east, Kishoreganj Sadar upazila on the west (Figure 1).

\subsection{Duration of the study}

The present study was undertaken for the period of 18 months from July 2017 to December 2018 in haor region, Kishoreganj. The necessary data were collected during the study period to fulfil the requirement of the research works. For the collection of the data it was needed to visit the study area about 1 month interval.

\subsection{Preparation of questionnaire}

The questionnaire was prepared to collect primary data from the study area of Kishoreganj haor. The questionnaire was consisted of all necessary questions that were essential for the details information about the fishers' livelihood data. The questionnaire has the five parts: these are personal information, fishing information, fishing constraints, socio-economic condition and conclusion. The fishers' were interviewed on the impact of climate change, biodiversity, human health, fisheries researches and their livelihood. The focus of this questionnaire survey was to determine the changes of fish production, livelihood, adaptability fisheries emigration due to the effects of climate change. 


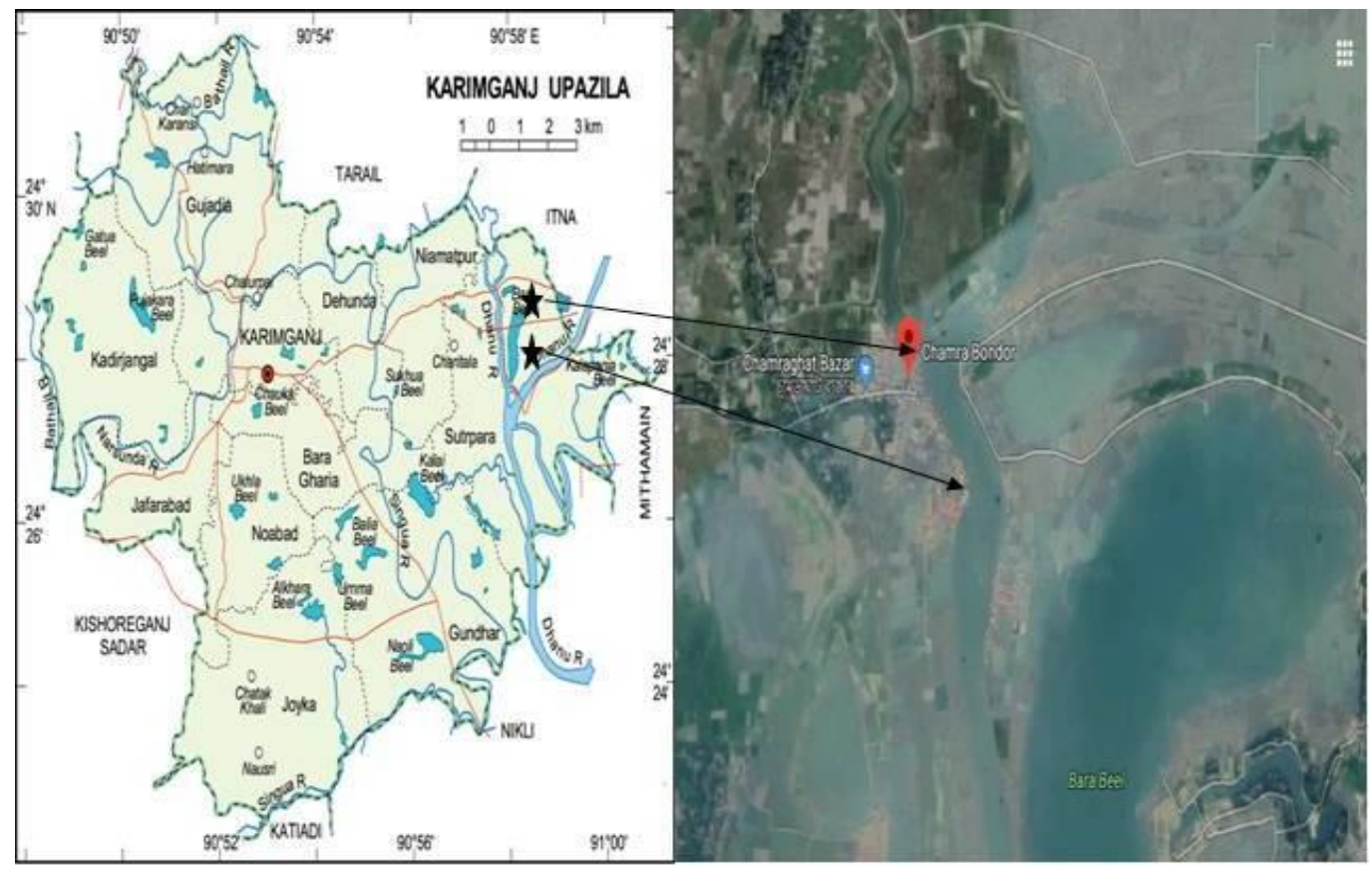

Figure 1. Location of the study area.

\subsection{Sampling size and sampling procedure}

Two hundred fishers' were selected to take the data for their livelihood in the Kishoreganj haor region. Among 200 interviewed people, they included both male and female. The family members were selected randomly for sampling.

\subsection{Data collection}

The fisher' livelihood data was collected through semi-structured questionnaire interview and Focused Group Discussion (FGD) method. Fishers' interview and FGD had been done in fish landing centers, fish market, boat owners of commercial fishing vessels, retailers, fish traders, local people, fishers, riverside settlers and fishers' village of those selected sampling areas for the collection of information on fisheries resources and livelihood data. Households were selected as the sampling unit considering the factors that one member of each household was permanent resident of the study area and was involved with fish catching or fish farming. The minimum age of each respondent was considered 40 years so that they could provide more accurate information.

The Secondary data was collected from various relevant scientific articles, reports, maps, journals, website, library, Bangladesh Fisheries Research Institute, Department of Fisheries and Department of Forestry.

\subsection{Sustainable livelihood approach (SLA)}

SLA is an attempt to recognize climate changes impact and variation fishers' community at Kishoreganj haor region. There are three major components such as livelihood asset (natural, financial, social, human and physical capital), vulnerability context (vulnerability analysis) and structure and process (institutional analysis) in the framework of SLA. The principle of the SLA into the regulation of community based climate change impact and adaptation in a specific way were maintained for the current study.

\subsection{Data processing and analysis}

From study area, the data were collected and sorted, edited, encoded, summarized, tabulated and analyzed according to the objectives of the study. Then carefully enter into IBM-SPSS 20. All the collected data were analyzed by IBM-SPSS 20 .

\section{Results and Discussion}

\subsection{Demographic information of the fishers}

In the present study, fishers' livelihood in Kishoreganj haor region was observed and found that male person was dominantly involved in fishing than female. On the other hand, women were mainly involved in household activity (39.29\%) and rearing domestic animal (21.43\%) for their extra income which is helpful for their family 
members. In our society, it is very difficult especially for female to go outside for fishing. In the study area, average household size was 6 and male and female ratio was 76.67 and 23.33, respectively. It was found that $39.17 \%$ and $9.17 \%$ people's age were $30-45$ and 15 , respectively. It indicates that a number of workable peoples are high. Ali et al. (2009) found quiet similar results that 50\% of the fishers belong to age group of 31-40 years in the district of Mymensingh. Sufian et al. (2017) reported that middle age group 31-45 years and Muslim fishers are the most dominant in Dekar haor of Sunamganj which is similar with the present study.

Religion is an important attribute in the cultural area in any society. Though conceived anthropologically, the low caste Hindus constitute the fishing communities in Bangladesh but now-a-days people of various castes, creed and status are found in fishing community (Azam et al., 1998). In the study area, 65\% fishers were Muslim and 35\% were Hindu. The study of the Chantarasri (1994), Rabbani and Sarker (1997) in the Sundarbans reserve forest also found quite similar results the most fishers were Muslim (68\%). Hindu fishers were found 32\% in Sundarbans (Ahmed and Hossain, 1999) and 57\% in Tangail district (Ahamed, 1996). Trina et al. (2016) found similar result in fishers' community in Dekhar haor under Sunamganj district that were 80\% Muslims and only $20 \%$ Hindu. It was found that $90.83 \%$ fishers of the study area were married and $9.17 \%$ were unmarried. Ahamed (1996) in Tangail, found that married fishers was 94\%, which is quite similar with the present study. In the present study area, it was found that $60 \%$ fishers lived in nuclear families and $40 \%$ lived with joint family. Sufian et al. (2017) reported the most of the fishers lived in joint family with members ranging from 6 to 11 in Dekar haor of Sunamganj. Ali et al. (2009) found that about 42\% of the fishers lived in nuclear family and rest $57.50 \%$ in the whole family in the district of Mymensingh. Rahaman et al. (2020) found that most of the fishers were belonged to the age groups of 41 to 60 years (45\%), represented by $75 \%$ muslim and joint family type $(61 \%)$ was the predominant among the fishers.

Human resource development and social advancement are dependent on the education. BBS (Bangladesh Bureau of Statistics) classifies literate persons as those who can write a letter in any language. In the present study, it was found that $6.67 \%$ had passed primary or above. About $12.5 \%$ fishers can sign only and $80.83 \%$ were illiterate. Sufian et al. (2017) found quite similar result that $57 \%$ fishers were illiterate due to economic crises and lack of awareness about education in Dekar haor. Mahbubullah (1986) and Ahamed (1996) were found literacy rate $23 \%$ and $69 \%$, respectively in the polder area and Tangail. In the present study, parents were not interested to send their children to school because of their financial problem. Only $21.31 \%$ children were going to school and $46.17 \%$ children were avoiding school for supporting their family due to lack of awareness program and financial problem. Sufian et al. (2017) reported that $41.15 \%$ fishers' children were found up to primary level, whereas $29.1 \%$ not schooling of children categories and $11.98 \%$ children dropped out of school before completing their primary education. The present study showed that most of the fishers are unable to maintain the education costs their school going children. Fishers' children enter into the fishing profession in their early age owing to poor economic status of their parents and lack of awareness about education. For this reason, the literacy rate is low among fishers' community.

In the present study, $65 \%$ fishers were involved in permanent fishing activity and 35\% fishers were temporarily involved in fishing with other occupation as daily labor, net making etc. Among all fishers $34.17 \%$ are doing illegal fishing during ban period. Ahamed (1996) found that about 34\% fishers depending on crop cultivation as subsidiary occupation in Tangail. Ahamed (1996) also found that $81 \%$ carried out fishing throughout the year.

The clean and safe drinking water is the right for the people of a nation. In the present study, $86.6 \%$ fishers used tube-wells for drinking water and 3.5\% fishers used pond water both for drinking and household work. The fishers' $(100 \%)$ of the old Brahmaputra river were used tube-well water for drinking purposes, among them $40 \%$ had their own tube-well, 50\% used shared tube-well and remaining 10\% used neighbours tube-well (Kabir et al., 2012). Most of the fishers lived in very poor housing conditions. From the survey, it was found that $73.6 \%$ house condition of the fishers was muddy house and $26.4 \%$ house condition was tin-shed. Mahmud et al. (2015) found that $14 \%$ fishers were lived in the house made straw and soil, $62 \%$ fishers were lived in the house made by tin. The present study revealed that $7.6 \%$ fishers had unhygienic and $92.4 \%$ fishers had semi-hygienic sanitation system. Ali et al. (2009) found that $62.5 \%$ of the fishers had semi-hygienic, $25 \%$ had unhygienic and $12.5 \%$ had hygienic toilet. The present results indicated that the fishers of the study area had better condition with respect to their sanitation facilities.

The present study revealed that only $43.33 \%$ of the fishers had electricity access while $46.73 \%$ of them had no electricity access. Shamima (2000) reported that the $20 \%$ of fishers had electricity in Gollamari fishing community, Khulna. Presents results indicate that the fishers of the present study areas had better condition with respects to the electricity consumption. The basic information of the fishers is represented in Table 1 . 


\subsection{Fishers' activity during ban period in the study area}

Illegal fishing was doing $34.17 \%$ during ban period and there were $14.17 \%$ day labourer. Other fishers were also involved in net making, agriculture and handicraft making etc. during ban period in the present study area. Activity during ban period is presented in Table 2. The result supports Bappa et al. (2014) that primary occupation of $60 \%$ respondents was fishing and few were also involved in agriculture. They noted that only $12 \%$ women were engaged in making nets for fishing.

\subsection{Women and children's activity in Kishoreganj haor region}

In the study area, $39.29 \%$ of women was housewife, $21.28 \%$ was involved in rearing domestic animals for contribution in their family. Few women were also involved in handicraft making, helping in fishing activity, helping in agriculture etc. In the present study area, women participation is increasing day by day. Women participation is presented in Table 3. Children activities were also observed during study period. Most of the children were avoiding school (46.17\%) for helping their family members. School going children was $21.31 \%$ in the present study area. Small percentage of the children was also involved in helping in fishing (7.38\%), helping in household activity (9.01\%) etc. Children's activity in Kishoreganj haor region is presented in Table 4. Sufian et al. (2017) found that women involved in net making, fish drying, poultry rearing, livestock rearing, cultivation (fruit and vegetables), handicraft and other household activities at the Dekar haor of Sunamganj in Bangladesh. The highest number of fishers' children (41.15\%) was found up to primary level followed by $29.1 \%$ not schooling and $17.17 \%$ secondary level. It is notable that $11.98 \%$ of the children dropped out of school before completing their primary education, this is similar to the present findings.

\subsection{Annual average income of fishers in the study area}

Most of the fishers' income was very low according to the fishers' opinion in the present study area. Based on field survey, $39.17 \%$ fishers' income range was 20,000-30,000 BDT and 32.5\% fishers' income was 30,000$50,000 \mathrm{BDT}$ in the present study area. Many fishers take loan from some NGO's and arotdar (moneyed man) for a long period of time. Only small percentage of the fishers (7.5\%) income was 70,000 BDT or above in the present study area. The annual average income of the fishers in the current study area is presented in Table 5. The result supports Trina et al. (2016) that 70\% peoples earned 40,000-60,000 BDT/year, 20\% earned 61,00099,000 BDT/year and 10\% earned 100,000-above BDT/year and also agrees with Bappa et al. (2014) that annual household income of maximum beneficiaries (44\%) was below 30,000 BDT and above 50,000 BDT found in only $4 \%$ cases.

\subsection{Major problems and constraints associated with fishing and livelihood}

It is seen that lack of knowledge was the most frequently faced problem (ranked $1^{\text {st }}$ ) by the fishers. $63.3 \%$ fishers stated about this problem. Low price of fishes was the $2^{\text {nd }}$ major problem and constraints in the present study area that $59.9 \%$ fishers was faced frequently and access to information and training (ranked $3^{\text {rd }}$ ) which were frequently faced by $57.5 \%$ fishers, respectively. Other problems and constraints included disease, unfavourable environment, and access to bank loans, safety, lack of foods and cloths, access to water and lack of fish storage which were ranked as $4^{\text {th }}, 5^{\text {th }}, 6^{\text {th }}, 7^{\text {th }}, 8^{\text {th }}, 9^{\text {th }}$ and $10^{\text {th }}$, respectively according to the fishers' opinion. Table 6 represents major problems and constraints faced by the fishers in the present study. Additionally, Islam et al. (2020), Rahaman et al. (2019) and Hossain et al. (2018) found that the catch per unit effort of fishers' nets was declined due to decreased species composition. Sufian et al. (2017) investigated the major problems and constraints associated with fishing and livelihood in Dekar haor of Sunamganj in Bangladesh. They noted that housing and sanitation conditions of the fishers were not well developed and the highest percentage of fishers were illiterate due to economic crises and lack of awareness about education. Kabir et al. (2012) noted that about $60 \%$ of the fishers used unhygienic while $10 \%$ used semi-hygienic and $30 \%$ of the fishers had no sanitary toilet facilities and also found $40 \%$ fishers used their own tube-well, 50\% used shared tube-well and remaining $19 \%$ used neighbours tube-well for drinking water.

\subsection{Fishers' perception about the impact of the climate change}

Fishers' perceptions about the impact of the climate change on their usual life were evaluated using agreement index (AI). Fishers comments on the impact of climate change were recorded 15 statements and their depth of agreements on the selected statements were calculated consequently. Table 7 represents agreement index regarding the impacts of climate change.

Climate change affected the livelihood, hampered fishing ground, fishing season in the present study area. Land pattern are changed due to siltation, river bank erosion is very much severe. Most of the fishers of the 
Kishoreganj haor region are dependent on only fishing for livelihood. A few numbers of fishers were related with non-fishing activity. Chowdhury et al. (2010) found that Bangladesh is highly vulnerable to the effects of climate change in fisheries. In the present study, it was observed that most of the fishers are found seasonal and they either do other works or stay at home. In this situation they increase the unemployment number and lead life below poverty level. Siddiquee et al. (2013) analyzed that trend of livelihood and food security had fallen largely below the poverty level.

In the present study, about $87.5 \%$ fishers said that flash flood was the most vulnerable problem in the present study area. Fishers said that the intensity and frequency of flash flood is higher than previous time. However, fishers understand that pattern of rainfall and frequency of heavy rainfall has been increased due to climate change (Vlassova, 2006). All of these physical changes can make fishing more challenging and lead to loss of land, loss of haor vegetation and reduced access to freshwater (Barnett and Adger, 2003). Thousands of people are affected by these hazards which destroy farm and homestead land, housing structure, standing crop, poultry and livestock, vegetation, household utensil and communication system. These losses force the peoples to move at new places without any alternative option and put them in disastrous situation to obliged drawn savings and often fall into further debt (Islam et al., 2006).

Table 1. Basic information about the fishers.

\begin{tabular}{lll}
\hline Particulars & & Percentages of fishers \\
\hline Average household size (no.) & & 6.00 \\
Average dependency ratio (no.) & & 2.23 \\
Average sex distribution & Male & 76.67 \\
Average age & Female & 23.33 \\
& Below15.00 years & 9.17 \\
& 15.01 to 30.0years & 32.50 \\
& 30.01 to 45.0years & 39.17 \\
Religion & 45.01 to 60.00 years & 19.17 \\
Marital status & Islam & 65.00 \\
Family type & Hindu & 35.00 \\
Average children (no.) & Unmarried & 9.17 \\
& Married & 90.83 \\
Literacy rate & Nuclear family & 60.00 \\
& Joint family & 40.00 \\
Occupational status & Male & 1.70 \\
Fishers type & Female & 1.30 \\
Housing condition & Illiterate & 80.83 \\
Source of drinking water & Sign only & 12.50 \\
Sanitation type & Primary and above & 6.67 \\
Everage fishing time (hr/day) & Fishing only (with licence) & 24.17 \\
& Fishing only (without licence) & 36.67 \\
& Fishing and others & 39.17 \\
& Permanent & 65.00 \\
& Temporary & 35.00 \\
& Muddy house & 73.60 \\
& Oin-shed & 26.40 \\
& Own tube well & 3.50 \\
& Others tube well & 42.00 \\
& Semhyienic & 54.50 \\
& & 7.60 \\
& & 92.40 \\
& & 9.00 \\
& & 43.33 \\
\hline
\end{tabular}


Asian J. Med. Biol. Res. 2020, 6 (3)

Table 2. Fishers activity during ban period.

\begin{tabular}{lll}
\hline Activity & Number & Percentage \\
\hline No activity & 07 & 5.83 \\
Net making & 12 & 10.00 \\
Illegal fishing (poaching) & 41 & 34.17 \\
Agriculture & 18 & 15.00 \\
Agriculture and illegal fishing & 11 & 9.17 \\
Handicraft making & 03 & 2.50 \\
Day laborer & 17 & 14.17 \\
Other & 11 & 9.17 \\
Total & 120 & 100 \\
\hline
\end{tabular}

Source: Field survey, 2017-2018.

Table 3. Women participation on livelihood in Kishoreganj haor region.

\begin{tabular}{lll}
\hline Activity & Number & Percentage (\%) \\
\hline Housewife & 11 & 39.29 \\
Handicraft making & 03 & 10.71 \\
Helping in fishing activity & 02 & 7.14 \\
Helping in agriculture & 02 & 7.14 \\
Rearing domestic animals & 06 & 21.43 \\
Others & 04 & 14.28 \\
\hline Total & 28 & 100 \\
\hline
\end{tabular}

Source: Field survey, 2017-2018.

Table 4. Children's activity in Kishoreganj haor region.

\begin{tabular}{lll}
\hline Activity & Number & Percentage (\%) \\
\hline School going children & 78 & 21.31 \\
School avoiding children & 169 & 46.17 \\
Helping in fishing & 27 & 7.38 \\
Helping in household activity & 59 & 16.12 \\
Others & 33 & 9.01 \\
\hline Total & 366 & 100 \\
\hline
\end{tabular}

Source: Field survey, 2017-2018.

Table 5. Annual average incomes of the fishers.

\begin{tabular}{lll}
\hline Income Range(BDT) & Number & Percentage (\%) \\
\hline $20,000-30,000$ & 47 & 39.17 \\
$30,000-50,000$ & 39 & 32.50 \\
$50,000-70,000$ & 25 & 20.83 \\
$70,000-$ above & 09 & 7.50 \\
\hline & Total=120 & 100 \\
\hline
\end{tabular}

Source: Field survey, 2017-2018. 
Table 6. Problems and constraints faced by the fishers.

\begin{tabular}{lllll}
\hline \multirow{2}{*}{ Problems identified } & \multicolumn{3}{c}{ Extent of problem (\% of fishers) } & Rank \\
\cline { 2 - 5 } & Frequent & Occasional & Rare & 1 \\
Lack of knowledge & 63.3 & 21.4 & 15.3 & 3 \\
Access to information and training & 57.5 & 29.2 & 13.3 & 2 \\
Low price of fishes & 59.9 & 26.3 & 13.8 & 6 \\
Access to bank loans & 39.3 & 31.7 & 30.0 & 5 \\
Unfavorable environment & 40.8 & 34.2 & 25.0 & 7 \\
Safety & 37.3 & 31.5 & 31.2 & 4 \\
Disease & 41.7 & 40.1 & 18.2 & 8 \\
Lack of foods and cloths & 35.1 & 33.7 & 31.2 & 9 \\
Access to water & 34.0 & 33.5 & 32.5 & 9 \\
Lack of fish storage & 33.4 & 33.1 & 33.6 & 10 \\
\hline
\end{tabular}

Table 7. Agreement index regarding the impacts of climate change.

\begin{tabular}{llcc}
\hline \multirow{2}{*}{ Statements } & & Fishers agreement & Weights \\
\cline { 2 - 3 } & Agreed & Disagreed & $1 / 15$ \\
Reduce fish production & $77 / 120$ & $43 / 120$ & $1 / 15$ \\
Damage fishing ground & $67 / 120$ & $53 / 120$ & $1 / 15$ \\
Blockage fish migration route & $73 / 120$ & $47 / 120$ & $1 / 15$ \\
Damage biodiversity & $81 / 120$ & $39 / 120$ & $1 / 15$ \\
Increase cost of fishing materials & $86 / 120$ & $34 / 120$ & $1 / 15$ \\
Increase temperature & $68 / 120$ & $52 / 120$ & $1 / 15$ \\
Enhance soil erosion & $62 / 120$ & $58 / 120$ & $1 / 15$ \\
Reduce rainfall & $77 / 120$ & $43 / 120$ & $1 / 15$ \\
Siltation and sedimentation & $69 / 120$ & $51 / 120$ & $1 / 15$ \\
Change water flow level & $71 / 120$ & $49 / 120$ & $1 / 15$ \\
Storm Severity & $96 / 120$ & $24 / 120$ & $1 / 15$ \\
Storm frequency & $86 / 120$ & $34 / 120$ & $1 / 15$ \\
Change spawning season & $63 / 120$ & $57 / 120$ & $1 / 15$ \\
Decrease fish reproduction & $87 / 120$ & $33 / 120$ & $1 / 15$ \\
Extinct fish species & $80 / 120$ & $40 / 120$ & - \\
Index score & 0.627 & 0.373 & - \\
Depth of agreement (\%) & 62.7 & 37.3 & \\
\hline
\end{tabular}

Source: Authors' estimation based on field survey, 2017-2018.

Note: Calculation of index score for agreed opinions $=(77 / 120 \times 1 / 15)+(67 / 120 \times 1 / 15)+(73 / 120 \times 1 / 15)+(81 / 120 \times$ $1 / 15)+(86 / 120 \times 1 / 15)+(68 / 120 \times 1 / 15)+(62 / 120 \times 1 / 15)+(77 / 120 \times 1 / 15)+(69 / 120 \times 1 / 15)+(71 / 120 \times 1 / 15)+$ $(96 / 120 \times 1 / 15)+(86 / 120 \times 1 / 15)+(63 / 120 \times 1 / 15)+(87 / 120 \times 1 / 15)+80 / 120 \times 1 / 15)=0.627$

Calculation of index score for disagreed opinions $=(43 / 120 \times 1 / 15)+(53 / 120 \times 1 / 15)+(47 / 120 \times 1 / 15)+(39 / 120 \times 1 / 15)$ $+(34 / 120 \times 1 / 15)+(52 / 120 \times 1 / 15)+(58 / 120 \times 1 / 15)+(43 / 120 \times 1 / 15)+(51 / 120 \times 1 / 15)+(49 / 120 \times 1 / 15)+(24 / 120 \times$ $1 / 15)+(34 / 120 \times 1 / 15)+(57 / 120 \times 1 / 15)+(33 / 120 \times 1 / 15)+(40 / 120 \times 1 / 15)=0.373$

Calculation of depth of agreement for agreed opinions $=0.627 \times 100=62.7 \%$

Calculation of depth of agreement for disagreed opinions $=0.373 \times 100=37.3 \%$

\section{Conclusions}

Climate change affected livelihood of the fishers. The socio-economic condition of the fisher in the adjacent area was not satisfactory. Fishers were deprived of many amenities. Due to climate change, fishers' communities are facing many serious problems such as diseases, lack of foods, lack of lands, lack of economics support and lack of other facilities. Flood, storm surge and soil erosion were common in Kishoreganj haor region. Climate change is a challenge for fishers' community in Kishoreganj region. So it is necessary to conduct awareness training programme on improve management of environmental risk and adaptive capacity.

\section{Acknowledgements}

Authors acknowledge to the Project Implementation Unit, National Agricultural Technology Program-Phase II Project (NATP-2), Bangladesh Agricultural Research Council (BARC), Farmgate, Dhaka-1215, Bangladesh for funding the project (no. CRG-718). 
Conflict of interest

None to declare.

\section{References}

ACIA, 2004. Impacts of a warming arctic: Climate impact assessment. Cambridge university press.

Adger WN, TP Hughes, C Folke, SR Carpenter and J Rockserom, 2005. Social-ecological resilience to coastal disasters. Science, 309: 1036-1039.

Ahamed NU, 1996. Report of the fishers socio-economic survey. Fisheries survey and monitoring program, department of fisheries, Tangail.

Ahmed M, 2012. Community led framework for estimation of sustainable exploitation level of fish reeds in Tanguar haor. Community based sustainable management of Tanguar haor Project-II, IUCN, SDC ( Swiss Agency for development and cooperation).

Ahmed N and MAR Hossain, 1999. A study on socio-economic aspect of coastal fishers in Bangladesh. Progress. agric., 10: 151-155.

Ali H, MAK Azad, M Anisuzzaman, MMR Chowdhury, M Hoque and MI Sharful, 2009. Livelihood status of the fish farmers in the fish farmers in some selected areas Tarakanda upazila of Mymensingh district. J. Agroforest. Environ., 3: 85-89.

Azam K, D Kamal and M Mostofa, 1998. Status and potential of mud crab (Scylla serrata) in Bangladesh. Integrated management of Gages floodplains and Sundarbans ecosysytem, MA Rahman, MS Shah, MG Murtaza and MA Matin (eds.), Khulna University, Bangladesh,

Badjeck MC, ES Allison, AS Halls and NK Dulvy, 2010. Impacts of climate variability and change on fisherybased livelihoods. Mar. Policy, 34: 375-383.

Bappa SB, MMM Hossain, BK Dey, S Akter and M Hasan-Uj-Jaman, 2014. Socio-economic status of fishers of the Marjat Baor at Kaliganj in Jhenidah district, Bangladesh. J. Fish., 2: 100-105.

Barnett J and WN Adger, 2003. Climate danger and atoll countries. Clim. Change, 61: 321-337.

Bennett S, D Scott, A Karim, I Sobhan, A Khan and SMA Rashid, 1995. Wetland resources specialist study, northeast regional water management plan. Bangladesh flood action plan (FAP)-6, Bangladeh.

Brander K, 2006. Assessment of possible impacts of climate change on fisheries, Wissenschaftliche beirat der bunderregierung globale umweltvera nderungen (WBGU), Berlin.

Chantarasri S, 1994. Integrated Resource Development of the Sundarbans Reserve Forest. Report on Resources management for the Sundarbans Reserve Forest. UNDP/FAO (5-171). BGD/84/056, Khulna, Bangladesh.

Chowdhury MSH, MM Rahman, M Koike, N Muhammed, KM Salahuddin, MA Halim and MJ Islam, 2010. Small-scale mehedi (Lawsonia inermis L.) farming in the central Bangladesh: a promising NTFP-based rural livelihood outside the forests. Small Scale Forest., 9: 93-105.

Dixon RK, J Smith and S Guill, 2003. Life on the edge: vulnerability and adaptation of African ecosystems to global climate change. Mitig. Adapt. Strateg. Glob. Chang., 8: 93-113.

Dobson DM, 2001. From ice cores to tree rings. In: Spray SL, McGlothlin KL (eds) Global climate change. Rowman and Littlefield Publishers, Inc., Oxford, UK, 31-58.

Duffy JE, 2003. Biodiversity loss, trophic skew and ecosystem functioning. Ecol. Lett., 6(8): 680-687. https://doi.org/10.1046/j.1461-0248.2003.00494.x

Ficke AD, CA Myrick and LJ Hansen, 2007. Potential impacts of global climate change on freshwater fisheries. Rev. Fish Biol. Fish., 17: 581-613.

Gill GJ and J Gerard, 1991. Seasonality and agriculture in the developing world: A problem of the poor and the powerless. Cambridge university press.

Halls AS, 2009. Addressing fisheries in the climate change and adaptation initiative. Fisheries resources development, melkong region.

Hossain MJ, MJ Sarker, MN Uddin, A Islam, IJ Tumpa and Z Hossain, 2018. Macrobenthos presence in the estuarine waters of the Meghna river, Ramghati, Laksmipur, Bangladesh. World Appl. Sci. J., 36: 598-604.

Hussain MM and MA Salam, 2007. Basic service delivery advocacy: review report. Development wheel (DEW), Dhaka.

IPCC, 2007a. The physical science basis. Contribution of working group I to the fourth assessment report.

IPCC, 2007b. Impacts, adaptation and vulnerability: contribution of working group II to the fourth assessment report of the intergovernmental panel on climate change. Cambridge university press.

Islam GMN, NMR Abdullah, KK Viswanathan and TS Yew, 2006. Augmenting fishers welfare and livelihood assets through community based management in Bangladesh. In $11^{\text {th }}$ Biennial Conference Association for the study of common property, Bali, Indonesia. 
Islam A, SS Basak and Z Hossain, 2020. Fish and plankton biodiversity in the Kishoreganj haor, Kishoreganj, Bangladesh. Genet. Aquat. Org., 4: 39-48.

Kabir KR, RK Adhikary, MB Hossain and MH Minar, 2012. Livelihood status of fishers of the old Brahmaputra River, Bangladesh. World Appl. Sci. J., 16: 869-873.

Kazal MMH, CC Villinueva, MZ Hossain and TK Das, 2010. Food security strategies of the people living in hoar areas: status and prospects. American international university of Bangladesh, Dhaka.

Mahbubullah M, 1986. Case study of polder and estuarine fisheries community in Bangladesh, Socio-economic study of tropical fishing community in Bangladesh. A report for food and agricultural organization (FAO), Rome.

Mahmud S, ML Ali and MM Ali, 2015. Present scenario on livelihood status of the fishers in the Paira river, southern Bangladesh: constraints and recommendation. Int. J. Fish. Aquat. Stud., 2: 23-30.

Miah MR, 2013. Enhancing food security through acclimatized species domestication in the haor region. ABC J. Adv. Res., 2: 49-65.

MRAG, 2011. Fisheries and livelihood, Fisheries Management Science Programme (FMSP). Marine Resources Assessment Group (MRAG), and Department for International Development (DFID), London.

Myrick CA and JJ Cech, 2003. The physiological performance of golden trout at water temperatures of 10$19^{\circ}$ C. Calif. Fish Game., 89: 20-29.

Nath PCD, SK Debnath, R Sharmin, S Benerjee, MG Faroque and MM Ali, 2010. A study on the fish biodiversity of Borulia haor, Nikli, Kishoregonj. Int. J. Biol. Sci., 1: 37-41.

Rabbani AG and MS Sarker, 1997. Study on the current status of the fish extraction and revenue collection from the Sundarbans Reserve Forest. A Project Thesis-Fisheries and Marine Resource Technology Discipline, Khulna University, Khulna, Bangladesh.

Rahaman MJ, NS Ema, MS Hossain, MM Rahman and Z Hossain, 2019. Effects of climate change on fisheries biodiversity of the Meghna, Laukhati and Galachipa river in Bangladesh. EurAsian J. Biosci., 13: 17051717.

Rahaman MJ, MS Hossain, MM Rahman and Z Hossain, 2020. Impacts of climate change on livelihood of the fishers' at the Meghna, Laukhati and Galachipa river in Bangladesh. Asian J. Med. Biol. Res., 6: 81-92.

Sarma PK, S Sarker and MA Hossain, 2010. To Encourage Rural Employment and Income Through Dry Fish (Shutki) Processing Farming Household in Kishoregonj District. Bangladesh J. Agricult., 3: 141-145.

Schiel DR, JR Steinbeck and MS Foster, 2004. Ten years of induced ocean warming causes comprehensive changes in marine benthic communities. Ecology, 85: 1833-1839.

Shamima A, 2000. Socio-economic conditions of fishing community: Gallamary fish market, Khulana. A project thesis in Fisheries and Marine Resource Technology Discipline, Khulna University, Bangladesh.

Siddiquee NU, SMA Rahman, MSA Bhuiyan, AKMA Rahman, MR Amin and AKFH Bhuiyan, 2013. Practice, preference and performance of cattle under peri-urban dairy management system in Mymensingh. Bangladesh J. Animal Sci., 42: 89-95.

Sufian MA, M Kunda, MJ Islam, ATU Haque and D Pandit 2017. Socioeconomic conditions of fishermen of Dekar Haor in Sunamganj. J. Sylhet Agril. Univ., 4: 101-109.

Sumaila UR, WW Cheung, VW Lam, D Pauly and S Herrick, 2011. Climate change impacts on the biophysics and economics of world fisheries. Nat. Clim. Chang., 1: 448-449.

Trina BD, NC Roy, SK Das and HJ Ferdausi, 2016. Socioeconomic Status of Fishers' community at Dekhar Haor in Sunamganj District of Bangladesh. J. Sylhet Agril. Univ., 2: 239-246.

Vlassova TK, 2006. Arctic residents ${ }^{e e}$ observations and human impact assessments in understanding environmental changes in Boreal forests: Russian experience and circumpolar perspectives. Mitig. Adapt. Strateg. Glob. Chang., 11: 897-909.

Westlund L, 2007. Disaster response and risk management in the fisheries sector. Food and Agriculture Organization, 479.

WFC, 2009. Vulnerability of national economies to the impacts of climate change on fisheries. Fish Fish., 10: 173-196. 